\title{
浅水部・深水部が交互に配置された 開水路流の抵抗特性
}

\section{FLOW RESISTANCE OF AN OPEN CHANNEL WITH ALTERNATIVELY ARRANGED RIFFLES AND POOLS}

\author{
道奥康治 ${ }^{1} \cdot$ 竹本修 ${ }^{2}$ 廣田宗明 ${ }^{3}$ \\ Kohji MICHIOKU, Osamu TAKEMOTO and Muneaki HIROTA \\ 1正会員 工博 神戸大学助教授 工学部建設学科（干657 神戸市灘区六甲台町1-1）

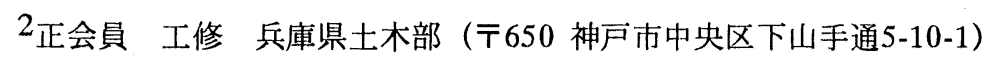 \\ 3 正会員 工学 同 上
}

\begin{abstract}
In recent years, so called "near-nature river works" are made in many river channels in order to create a suitable hydrospheric environment and ecosystems. The channel is required not only to provide good water environment but also to transport water mass without any hydraulic engineering troubles. In the present paper a fundamental experiment was carried out to examine an open channel flow resistance and characteristics, where simplified models of riffles and pools are alternatively arranged along the channel. The friction factor is correlated as a function of longitudinal interval of riffles, approaching angle of the riffle element and other hydraulic parameters of riffles and pools' geometry. It is expected the present research work to be a useful measure to determine river bed dimensions, so that a river channel design might be optimized to construct a best cross section not only for water environment but also for hydraulic functions of river channel.
\end{abstract}

Key Words : flow resistance, open channel flow, riffles and pools, compound cross section near-nature river works, river restoration

\section{1.はじめに}

近年の河川改修では，瀬や淵，中州を設けて， 変化に富む河道線形を設置したり，水性植物や自 然石ブロックの施工により護岸性能を向上させる 工法が使われる。このように河川環境に配慮した 改修では，工作物が潤辺の流水抵抗を增大させる 場合もあり，河川の治水・利水機能を損なわない ように,流水抵抗の的確な評価により河道断面を合 理的に設計する必要がある1).

本研究では, 瀬や淵の人為的設置を想定して浅 水部と深水部が交互に配置された開水路流れを実 験的に模擬し，水理特性を検討する。まず，種々 の河道形状に対して, 流速計測を実施し流れの構 造を把握する。次に, 壁面摩擦力と河道線形に起 因する形状抵抗力とを個別に評価して各々の抵抗 則を求め, 運動量保存則に基づいて流れの全抵抗 力を推定し実験值との比較検証を行う。

\section{2. 対象とする流れ}

一般に，流れに多様性を持たせる河道改修で は, 河道空間内に(1)流れの緩急, (2)水深の大小, (3)潤辺の粗滑をつけることを目的としている. 本研究では,図-1に示す開水路によって流れの多様 性を表現する。波長入で深水部と浅水部を交互に 配置し浅水部上面には粗度要素を設置すること により，上記(1)〜 (3)が再現される。

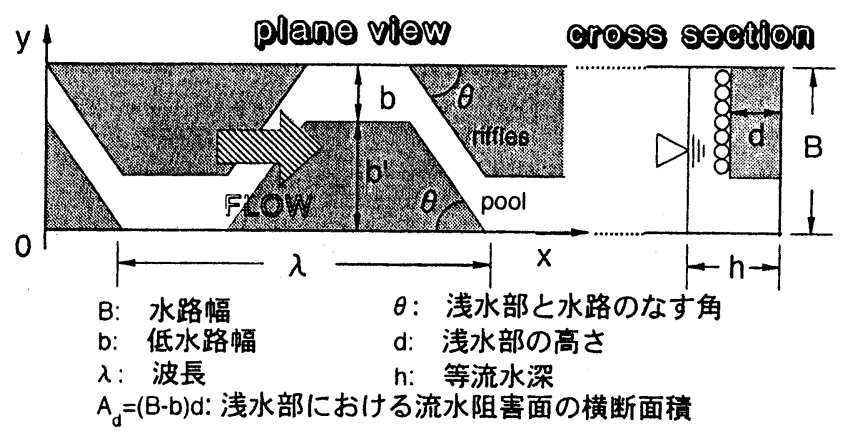

図-1 対象とする河道形状と諸量の定義 
表-1＼cjkstart流速計測に関する実験の条件(Series-V) (全ケースに対してR=3.60c m.)

\begin{tabular}{|c|c|c|c|c|c|c|c|c|c|c|}
\hline Case No. & $R / \lambda$ & $\theta(\mathrm{deg})$ & $d / R$ & $h(\mathrm{~cm})$ & $d(\mathrm{~cm})$ & $\lambda(\mathrm{cm})$ & $Q(1 / \mathrm{sec})$ & $\left(\times 10^{-3}\right)$ & $\operatorname{Re}\left(\times 10^{3}\right)$ & $F r$ \\
\hline $\mathrm{V}-1$ & \multirow{3}{*}{0.0243} & 45 & \multirow{4}{*}{0.779} & \multirow{4}{*}{6.50} & \multirow{4}{*}{2.80} & \multirow{3}{*}{148} & 4.40 & 1.25 & 7.59 & 0.313 \\
\hline V.2 & & 75 & & & & & 4.38 & 1.00 & 7.54 & 0.311 \\
\hline $\mathrm{V}-3$ & & 90 & & & & & 4.38 & 1.18 & 7.55 & 0.311 \\
\hline V-4 & 0.0152 & \multirow{2}{*}{45} & & & & 236 & 4.19 & 1.18 & 7.23 & 0.299 \\
\hline V-5 & 0.0243 & & 0.501 & 5.70 & 1.80 & 148 & 4.27 & 0.67 & 7.38 & 0.308 \\
\hline
\end{tabular}

表-2 抵抗特性に関する実験の条件

(a) 全潤辺が滑らかな場合(Series-S)

$\mathrm{S}-1$ は直線複断面水路, $\mathrm{S}-3$ は基準ケース.全ケースに対し $R=2.35 \mathrm{~cm}$. 網掛けを施したケースでは水面変位も計測.

\begin{tabular}{|c|c|c|c|c|c|c|c|c|c|c|}
\hline Case No. & $R / \lambda$ & $\theta(\operatorname{deg})$ & $d / R$ & $h(\mathrm{~cm})$ & $d(\mathrm{~cm})$ & $\lambda(\mathrm{cm})$ & $Q(1 / \mathrm{sec})$ & $I\left(\times 10^{-3}\right)$ & $\operatorname{Re}\left(\times 10^{3}\right)$ & $F r$ \\
\hline$S-1$ & 0 & 7 & 0.212 & 3.00 & 0.50 & $\infty$ & $2.11 \sim 8.29$ & $0.50 \sim 5.0$ & $4.18 \sim 16.2$ & $0.348 \sim 1.35$ \\
\hline S-2 & 0.0118 & \multirow{5}{*}{45} & \multirow{9}{*}{0.212} & \multirow{9}{*}{3.00} & \multirow{9}{*}{0.50} & 200 & $1.73 \sim 10.8$ & $0.50 \sim 10.0$ & $3.37 \sim 20.8$ & $0.280 \sim 1.73$ \\
\hline (5) & 0.0159 & & & & & 148 & $1.80 \sim 8.44$ & $0.50 \sim 6.7$ & $3.50 \sim 16.3$ & $0.291 \sim 1.36$ \\
\hline$s-4$ & 0.0181 & & & & & 130 & $1.85 \sim 7.12$ & $0.50 \sim 5.0$ & $3.62 \sim 13.8$ & $0.302 \sim 1.15$ \\
\hline S.5. & 0.0226 & & & & & 104 & $2.16 \sim 11.1$ & $0.67 \sim 14.0$ & $4.17 \sim 21.8$ & $0.347 \sim 1.81$ \\
\hline S.6. & 0.0274 & & & & & 86 & $1.73 \sim 8.41$ & $0.50 \sim 8.0$ & $3.38 \sim 16.5$ & $0.282 \sim 1.37$ \\
\hline S 7. & \multirow{6}{*}{0.0159} & 30 & & & & \multirow{6}{*}{148} & $2.01 \sim 7.84$ & $0.50 \sim 5.7$ & $3.99 \sim 15.6$ & $0.333 \sim 1.30$ \\
\hline S.8 & & 60 & & & & & $1.77 \sim 6.64$ & $0.52 \sim 5.0$ & $3.41 \sim 13.1$ & $0.284 \sim 1.09$ \\
\hline S-9 & & 75 & & & & & $1.76 \sim 6.38$ & $0.50 \sim 4.4$ & $3.42 \sim 12.5$ & $0.286 \sim 1.04$ \\
\hline S-10 & & 90 & & & & & $1.93 \sim 7.05$ & $0.50 \sim 5.0$ & $3.79 \sim 14.0$ & $0.316 \sim 1.17$ \\
\hline S-11 & & \multirow{2}{*}{45} & 0.765 & 3.96 & 1.80 & & $2.50 \sim 6.18$ & $1.4 \sim 6.5$ & $4.73 \sim 11.7$ & $0.386 \sim 0.95$ \\
\hline S-12 & & & 1.19 & 4.71 & 2.80 & & $2.39 \sim 5.72$ & $1.7 \sim 8.1$ & $4.40 \sim 10.5$ & $0.355 \sim 0.848$ \\
\hline
\end{tabular}

(b) 浅水部に粗度を設置した場合(Series-R) R-7は直線複断面水路.全ケースに対し $d=1.48 \mathrm{~cm}, I=1 / 400$.

\begin{tabular}{|c|c|c|c|c|c|c|c|}
\hline Case No. & $d / \lambda$ & $\theta(\mathrm{deg})$ & $\lambda(\mathrm{cm})$ & $Q(1 / \mathrm{sec})$ & $h(\mathrm{~cm})$ & $\operatorname{Re}\left(\times 10^{3}\right)$ & $F r$ \\
\hline $\mathrm{R}-1$ & 0.0172 & \multirow{4}{*}{45} & 86 & $0.69 \sim 7.69$ & $2.55 \sim 6.11$ & $1.38 \sim 13.4$ & $0.265 \sim 0.531$ \\
\hline $\mathrm{R}-2$ & 0.0142 & & 104 & $0.85 \sim 7.99$ & $2.68 \sim 6.18$ & $1.68 \sim 13.9$ & $0.289 \sim 0.541$ \\
\hline $\mathrm{R}-3$ & 0.00998 & & 148 & $1.70 \sim 7.69$ & $3.15 \sim 5.76$ & $3.31 \sim 13.6$ & $0.405 \sim 0.586$ \\
\hline R-4 & 0.00616 & & 240 & $1.28 \sim 8.91$ & $3.10 \sim 5.59$ & $2.50 \sim 15.9$ & $0.314 \sim 0.714$ \\
\hline R-5 & \multirow{2}{*}{0.00998} & 30 & \multirow{2}{*}{148} & $2.08 \sim 8.83$ & $3.31 \sim 5.95$ & $4.03 \sim 15.5$ & $0.446 \sim 0.638$ \\
\hline $\mathrm{R}-6$ & & 60 & & $1.98 \sim 8.75$ & $3.38 \sim 6.12$ & $3.82 \sim 15.3$ & $0.406 \sim 0.603$ \\
\hline R-7 & 0 & & $\infty$ & $0.96 \sim 9.56$ & $1.96 \sim 5.74$ & $1.70 \sim 14.4$ & $0.624 \sim 0.743$ \\
\hline
\end{tabular}

交互砂州が発達した河川における流れはこれ

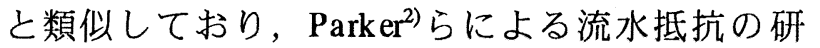
究は本文と関連性が深い。

\section{3. 実験方法}

\section{(1)装置亡方法}

実験水路は，長さ $7 \mathrm{~m} ，$ 幅 $45 \mathrm{~cm}$ ，深さ $20 \mathrm{~cm}$ の 透明アクリル樹脂製である。実験は常流の等流 状態で行われた。流速は，二次元電磁流速計を用 いて，サンプリング周波数 $10 \mathrm{~Hz}$ で 60 秒間計測し た. 縦断方向 3 断面, 横断方向 $4 \sim 5$ 点の計 $12 \sim 15$ 点 に㧍いて水哚をポイントゲージで計測し, 平均水 深を求めた．水面変位の平面分布は，さらに密な 水深計測から求められた。水理諸量は, 水路中央 付近の水路床形状一波長を対象に計測された。

\section{(2) 実験条件}

図-1の開水路流に関連する水理量を用いて,抵抗 係数 $f \equiv 8 g R I / U^{2}$ を支配する無次元量が次式のよう にあらわされる。

$$
f=\text { Func. }\left(\frac{R}{\lambda}, \theta, \frac{d}{R}, \frac{R}{B}, \frac{R}{b}, R e, F r\right)
$$

ここで, $R e \equiv U R / v:$ Reynolds数, $F r \equiv U / \sqrt{g D}$ :

Fr ou de数, $R \equiv\{B h-d(B-b)\} /(B+2 h)$ : 径深, $D \equiv A$ $/ B$ : 水理学的水深, である。本実験では, さら に, $B=45 \mathrm{~cm}, b=15 \mathrm{~cm}$ と条件を固定し，式(1)を 次のように簡略化する。

$$
f=\text { Func. }\left(\frac{R}{\lambda}, \theta, \frac{d}{R}, R e, F r\right)
$$

式(2)を参考にして条件を設定し，次のような二種 類の実験を実施した。

(1) 流速計測に関する実験(Series-V, 表-1)

水路床形状と流れ特性の相関性を調べる目的で, 表-1のような条件のもとに流速計測を行った，径 深 $R$ は $R=3.60 \mathrm{~cm}$ と固定され， $R e \fallingdotseq 7,500$ となるよ うに水路床勾配功調節された。

(2) 抵抗特性に関する実験(表-2)

抵抗係数を算出するために

・全潤辺が滑らかな場合(Series-S)

・浅水部に粗度を設置した場合(Series-R)

・直線複断面開水路(S-1, R-7) 

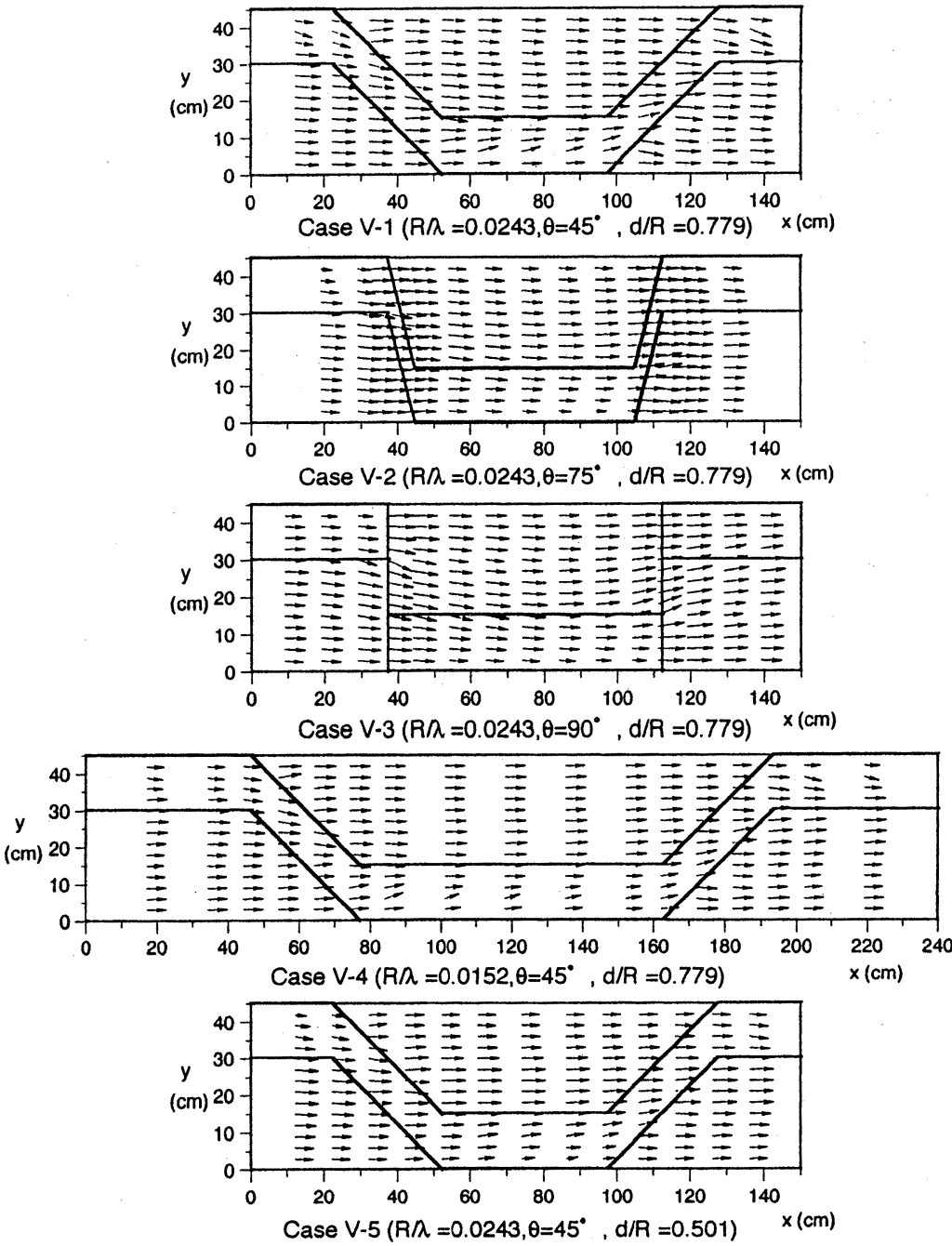

図-2 水面付近 $(\mathrm{z}=3.8 \mathrm{~cm})$ における二次元平面流況の比較 $($ Series-V)

の三種類の条件のもとで実験を行った．表-2に実 験条件を示す. Case S-1 とR-7は，浅水部が各々滑 面と粗面の場合の直線複断面開水路である. 滑面 はアクリル壁，粗面は粒径 2〜 4.75mm の砂粒を壁 面に張り付けたものからなる. 粗面の場合の相当 粗度高さは $k_{\mathrm{s}}=2.77 \mathrm{~mm}$ である. Series-S のうち網掛 けのCaseでは, 水路床形状と水位偏差との関係を 調べるために，ポイントゲージにより縦横断方向 $3 \mathrm{~cm}$ の間隔で水位計測を行った. Series-Sの実験で は, $R=2.35 \mathrm{~cm}$ に固定して水路床勾配 $I$ 変化させる ことによって, Series-Rの実験では, $I=1 / 400$ に固定 して径深Rを変化させることによって，それぞれ表 中のレイノルズ数の範囲で流水抵抗を計測した.

\section{4. 流況特性}

\section{(1) 水面近傍における平面二次元流速べクトル}

表-1のSeries-Vの各ケースにおける流況を図-2に 示す.いずれも水面近くで計測された $(\mathrm{x}, \mathrm{y})$ 二次 元平面内の流速ベクトルを表している。いずれ
のケースにおいても，太線であらわした深水部 形状に沿うように流れの蛇行が観察される。し 小し，流線形状は水路床の幾何条件によってか なり異なる.Case V-1に比べ，迎え角㫙大きな V-2では，流れが水路床の曲がりに追随せずに 浅水部へ乗り上げ，流線の曲がりはV-1ほど大 きくない. Case V-3は， $\theta=90^{\circ}$ で，非現実的な河 床形状であるが，暗極限值をとる場合の流れ の挙動を参考的に示している。㫙V-1と等し く, 波長 $\lambda \sigma$ 長いCase V-4では, 浅水部の流下方 向距離が長く,浅水部へ乗り上げた流れの直進性 が高い。深水部の屈曲部に扮けるV-1とV-40流 線形は類似している，浅水部の高さdがV-1より も低いCase V-5では, 水路床形状の影響は小さ く，水面近傍の流速べクトルには顕著な流線の 曲がりは見られない。

図-3にCase V-1の各水深に打ける流速べクトル を示す。底面に近いほど，流れは水路床形状に 沿う傾向が強くなっている，底面から離れるに したがい, 水路床形状に沿う流線形から水路側 

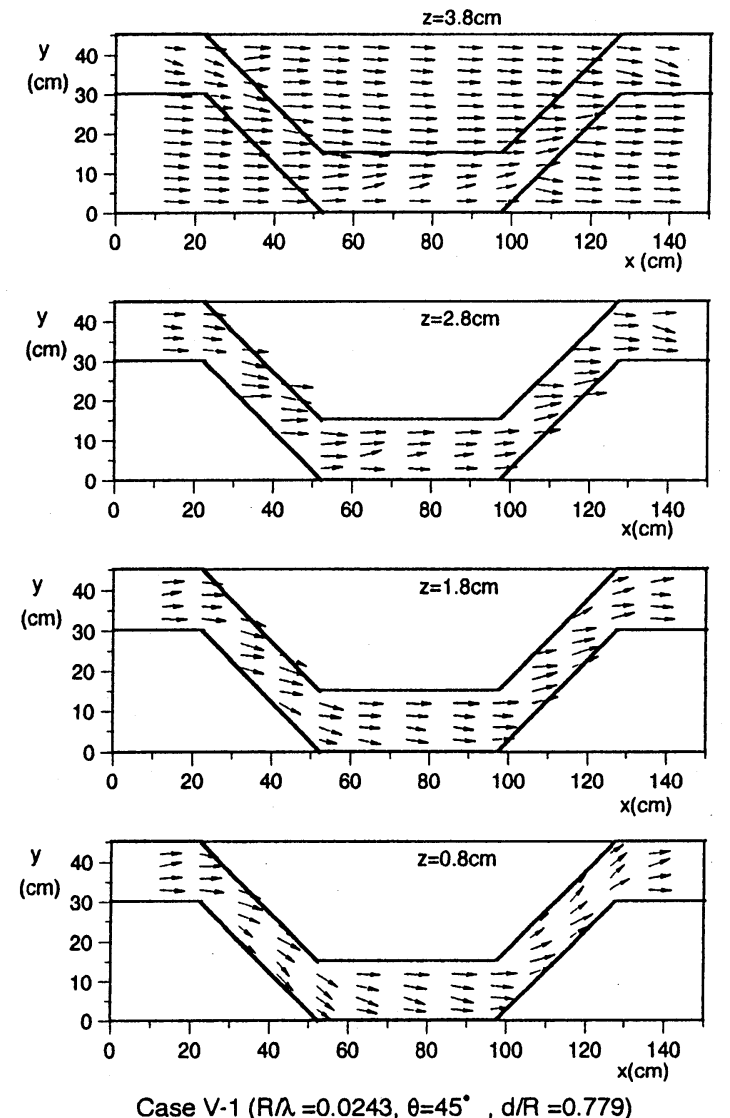

図-3＼cjkstart各水深毎の流速ベクトル(Case V-1)

壁に沿う直進的な流線へと移行している。この ように浅水部と深水部が交互に配置された開水 路流においては，媣水部に沿って蛇行しようと する下層流と，側壁法線に沿って直進しようと する上層流の間に強いせん断力が働いているこ とが推察される。

\section{(2) 水面変位}

図-4は, 各種水路床形状に対する水面変位の 分布を示す. 平均水位 $h($ 約 $3 \mathrm{~cm})$ 加らの鉛 直偏 差 $\Delta H$ を濃淡によって表わす。その正值 (濃い部 分)は $h$ より水位が大きいことを意味する．水路 床の幾何形状に対応して波状の水面変位が観測 されている。「深水部一浅水部」間の境界面と流 れが斜めに交差する水衝部において，水面波が 特に顕著に見られ，その波峰線は深水部法線 と ほぼ平行である。斜めの深水部に沿って水位は 上昇し，その前後の浅水部では水位が下降して いる。深水部が側壁と斜めに交差する屈曲部で は，側壁との相互干渉による反射波もあらわれ， 複雑な水位分布を呈している. 波長入が大き $<, R / \lambda$ 小さいケースほど, 定常波の数が増加 している.

図-5には, 迎え角㫙ともなら水面分布の差異 をあらわす， $\theta=30^{\circ}$ では，深水部線形に平行な
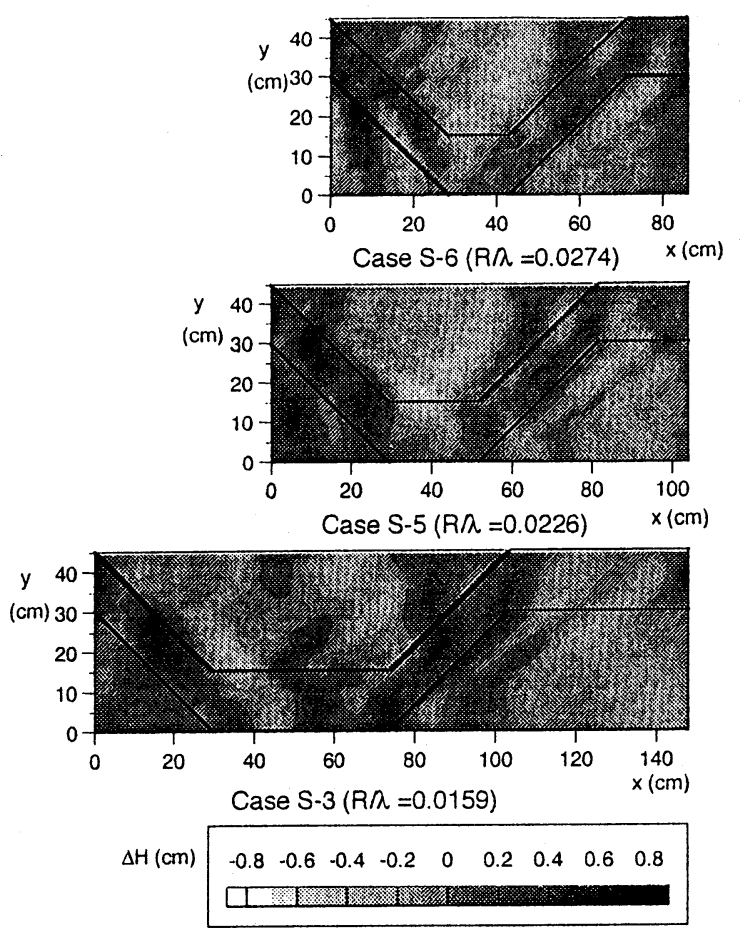

図-4 $R / \lambda$ にもなう水阿変位 0 変化 $\left(\theta=45^{\circ}\right)$
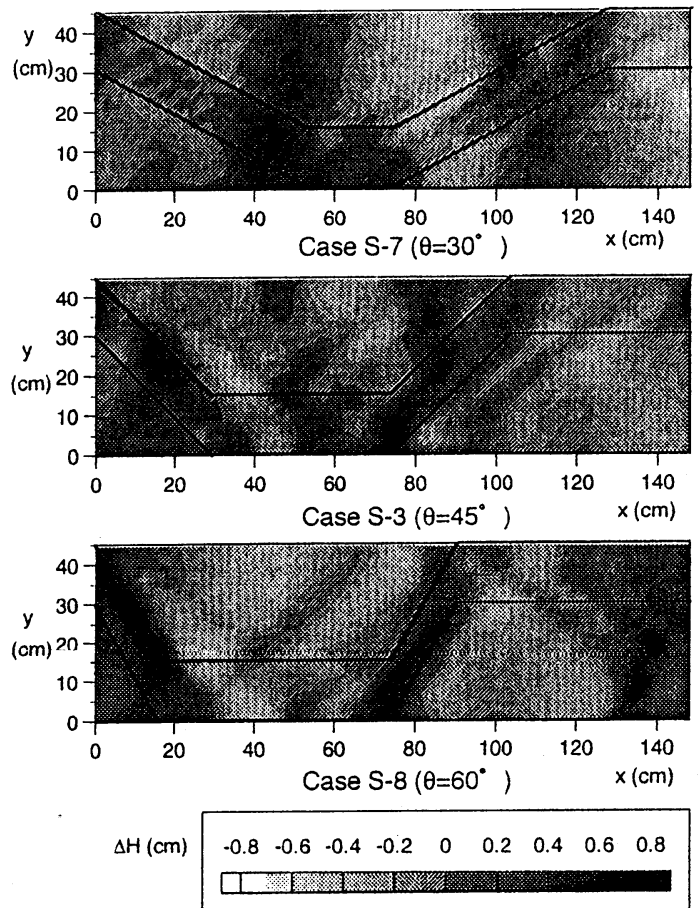

図-5 $\theta$ にともなう水面変位の変化 $(R / \lambda=0.0159)$

波峰線は明瞭ではないが， より大きな定常波が発達し，その峰線は深水部 の線形に平行になる。図-5より，この は, $\theta$ の増加とともに流れのエネルギーが造波 に費やされ，水路床の形状に起因する流水抵抗 が増加すると考えられる。

\section{5. 流水抵抗の評価}

ここで対象とする流れの抵抗力は，(1)壁面摩 


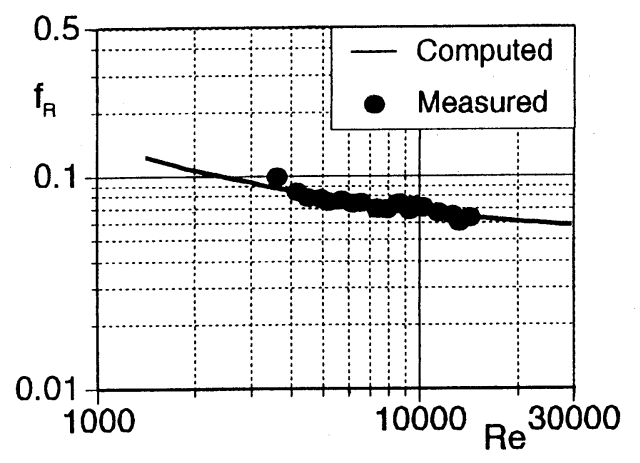

図-6 粗面の摩擦損失係数 $f_{\mathrm{R}}$ [式(3)との比較 $]$

擦力之(2)水路床形状に起因する抗力からなると 考える。

\section{(1) 壁面摩擦力}

複断面直線開水路の実験より, 壁面摩擦力が評価 される。全潤辺が滑面の場合の摩擦損失係 数 $f_{0}=8 g R I / U^{2}$ はおおよそBlasiusの式にしたがう(後述 の図-7). 潤辺に相当粗度高さ $k_{\mathrm{s}}=2.77 \mathrm{~mm}$ の砂粒を張 り付けた場合, 摩擦損失係数 $f_{\mathrm{R}}$ は図-6のように粗滑 遷移領域の抵抗則

$$
\sqrt{\frac{1}{f_{\mathrm{R}}}}=2.10+2.03 \log \left(\frac{175}{\operatorname{Re} \sqrt{f_{\mathrm{R}}}}+\frac{k_{\mathrm{S}}}{h}\right)
$$

に従うことが確認される。なお，この粗面の場合の Manningの粗度係数は $n=0.0156 て ゙ 一$ 定であった.

\section{(2) 水路床形状に起因する抵抗力 ${ }^{3)}$}

全潤辺滑面の直線複断面水路(Case S-1) と各種 幾何条件の開水路(全潤辺滑面)における実験 值(Series-S)との比較から，水路床形状に関するパラ メーター $(R / \lambda, \theta, d / R)$ 之摩擦損失係数 $f$ との相関関係 が実験的に得られる。一例として，R/Aとfとの相関 関係を図-7に示す。いずれのR/入に対しても図のよ うに, Blasius則と同様の関数形

$$
f=K \cdot R e^{-1 / 4}
$$

によって記述できる．他の二つの形状パラメータ 一 $(\theta, d / R)$ を変化させた場合においても, 高い相関 で式(4)の関数形が成立することを確認した. また，

図-7に示すように直線複断面開水路 $(R / \lambda=0$, Case $S$ 1)の場合，Blasius則にほぼ一致している.

形状抵抗力を抗力係数 $C_{\mathrm{D}}$ によって記述するために,

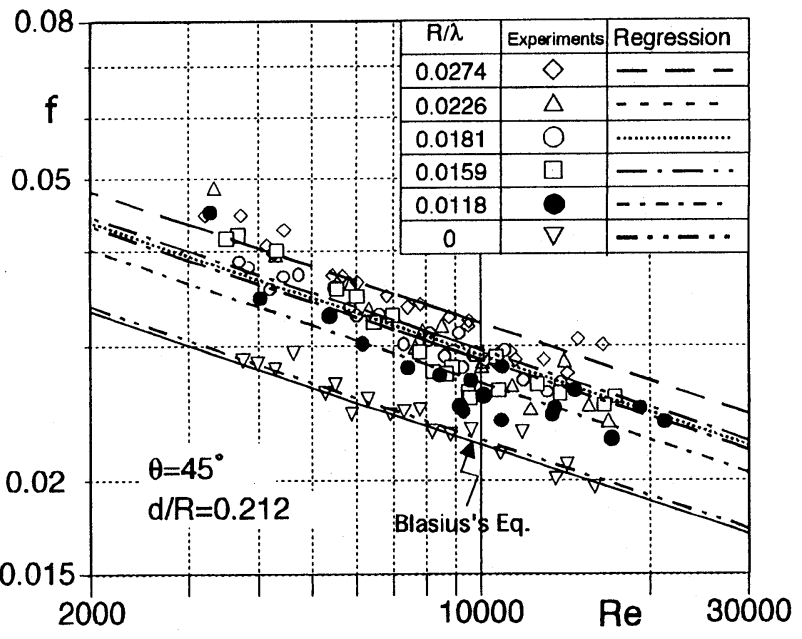

図-7 摩擦損失係数 $f(R e, R / \lambda)$ の関係(Series-S)

全潤辺が滑らかな開水路において，水路縦断方向半 波長入あたりの力のつり合いを考える.

$$
\frac{\rho}{2} g \lambda A I-\frac{1}{2}(B+2 h) \lambda \tau_{0}-\frac{\rho}{2} C_{\mathrm{D}} U^{2} A_{\mathrm{d}}=0
$$

ここで，第1項は重力, 第2項は壁面摩擦力, 第3 項 は形状抵抗力であり, $A_{\mathrm{d}}=(B-b) d は$, 浅水部における 流水阻害面の横断面積(図-1の横断面図における塗り つぶし部分)である。

式(5)に，直線複断面開水路の壁面せん断 力, $\tau_{0}=f_{0} \rho U^{2} / 8$ (ここで, $\left.f_{0}=K_{0} R e^{-1 / 4}\right)$, および全摩擦抵 抗係数 $f$ よって表した断面平均流速 $U=\sqrt{8 g R I / f}$ を代入する.ここで， $f$ と $f_{0}$ に含まれる式(4)中の係 数 $K, K_{0}$ は, 図-7のようにして実験值加らの回帰分析 により求める.これにより, 式(5)からC る。表-2中に○で記した基準ケース(Case S3: $\left.R / \lambda=0.0159, \theta=45^{\circ}, d / R=0.212\right)$ における抗力係 数 $C_{\mathrm{DS}}$ を用いて, 各水路床形状の抗力係数 $C_{\mathrm{D}}$ を無次 元化する.これを $(R / \lambda, \theta, d / R) 0$ 関数として図-8, 9, 10に示す. 図中の曲線は次のような回帰式である.

$$
\frac{C_{D}}{C_{D S}}\left(\frac{R}{\lambda}\right) \equiv F\left(\frac{R}{\lambda}\right)=0.904
$$

$\frac{C_{D}}{C_{D S}}(\theta) \equiv G(\theta)=-\frac{1.83}{10^{5}} \theta^{3}+\frac{2.41}{10^{3}} \theta^{2}-\frac{6.94}{10^{2}} \theta+0.958(7)$ $\frac{C_{D}}{C_{D S}}\left(\frac{d}{R}\right) \equiv H\left(\frac{d}{R}\right)=0.161\left(\frac{d}{R}\right)^{2}+0.0563\left(\frac{d}{R}\right)+0.981$

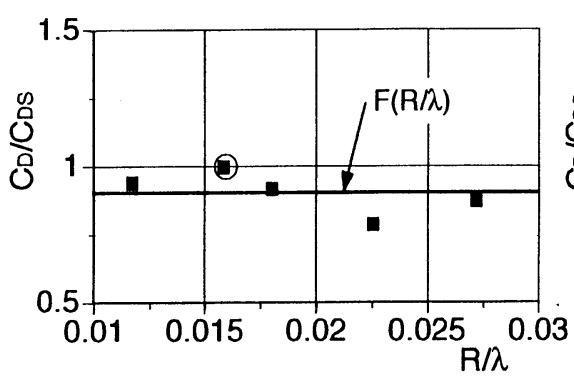

図-8 $\quad C_{\mathrm{D}} / C_{\mathrm{DS}} \sim R / \lambda \sigma$ 関係

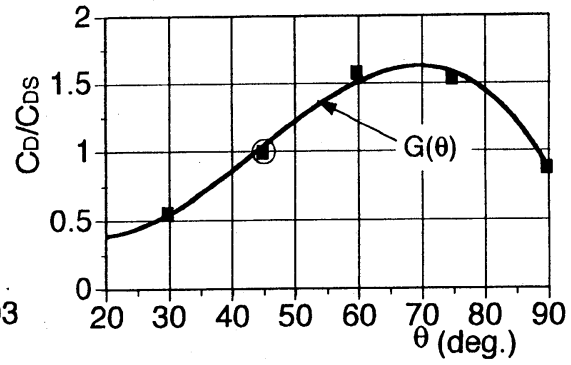

図-9 $\quad C_{\mathrm{D}} / C_{\mathrm{DS}} \sim \theta$ の)関係

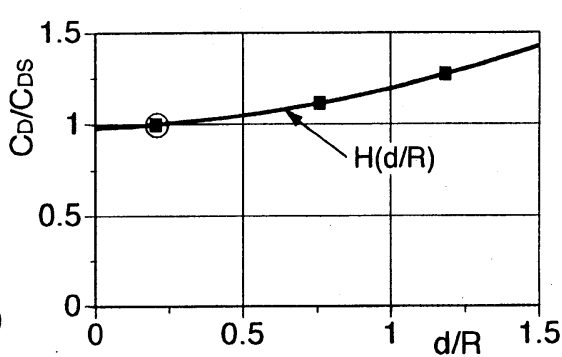

図-10 $\quad C_{\mathrm{D}}^{\prime} / C_{\mathrm{DS}}^{\prime} \sim d / R \sigma$ 関係 


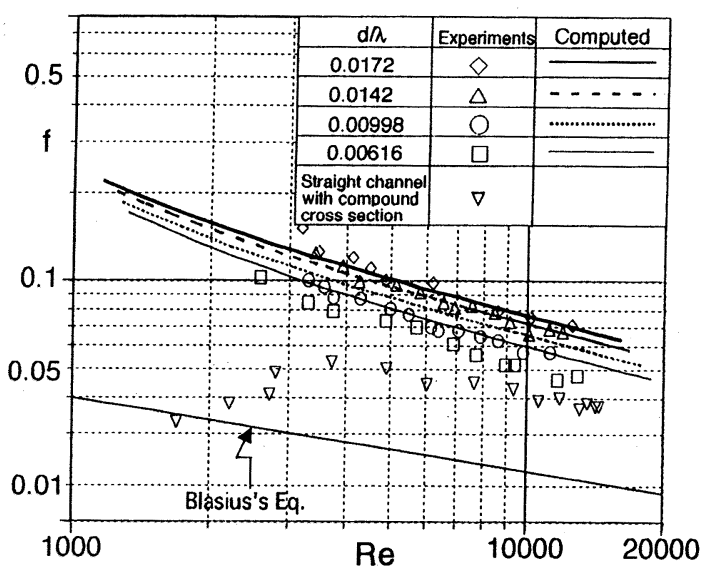

図-11 摩擦損失係数 $f$ 之 $(R e, d / \lambda) \sigma$ 関係(Series-R) ように定式化される.

$$
\frac{C_{D}^{\prime}}{C_{D S}}\left(\frac{R}{\lambda}, \theta, \frac{d}{R}\right)=F\left(\frac{R}{\lambda}\right) G(\theta) H\left(\frac{d}{R}\right)
$$

\section{6. 浅水部が粗面の水路における流水抵抗}

以上のように評価された抗力係数 $C_{D}$ を用いて, 浅 水部上端面に粗度を配した場合(Series-R)の抵抗係数 を評価する. 前と同様に半波長あたりの運動量のつ り合い式は次のようである.

$$
\begin{aligned}
\frac{\rho}{2} g \lambda A I- & \frac{1}{2}(b+2 h) \lambda \tau_{0}-\frac{1}{2}(B-b) \lambda \tau_{\mathrm{R}} \\
& -\frac{\rho}{2} C_{\mathrm{D}} U^{2} A_{\mathrm{d}}=0
\end{aligned}
$$

上式中，粗面の浅水部におけるせ九断 力 $\tau_{\mathrm{R}}=\rho f_{\mathrm{R}} U^{2} / 8$ は式(3) $) f_{\mathrm{R}}$ から, 滑面部の壁面摩擦 $\tau_{0}$ は 先の $f_{0}$ から, 形状抵抗力は式(9)のC $C_{\mathrm{D}}$ 少ら, 各々が評 価される. 所定の水理条件のもとで式(10)を断面平 均流速Uに関して解けば，水路全体の抵抗係数价算 出される。

様々な $d / \lambda に$ 対する $f$ と $e$ の関係を実験結果ととも に図-11に示す．さらに，図-12 はパラメーター を $\theta$ とした場合の $f$ と $e$ の関係, 図-13は $f$ と無次元水 深h/dの関係をそれぞれ表している，各図の曲線群は 式(10)加算定された $f$ 解析値である. 実際には， 断面内の高速部亡低速部の流速差に起因する内部せ ん断力が働いている. 式(10)の運動量式に内部せん 断力の効果を反映させることができれば，実験值と の適合度がさらに改善されるかもしれない。

\section{7. むすび}

浅水部と深水部が混在する開水路の流況や流水抵 抗など水理特性を実験的に検討した：実河川の形状 は多様であり，多自然的に改修された河川が本研究 における開水路形状によって精確に記述されている

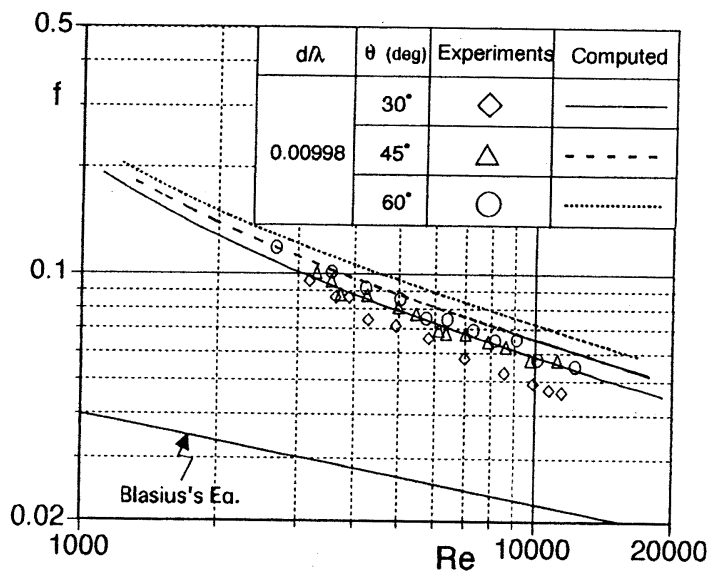

図-12 摩擦損失係数 $f$ と $(R e, \theta)$ の関係(Series-R)

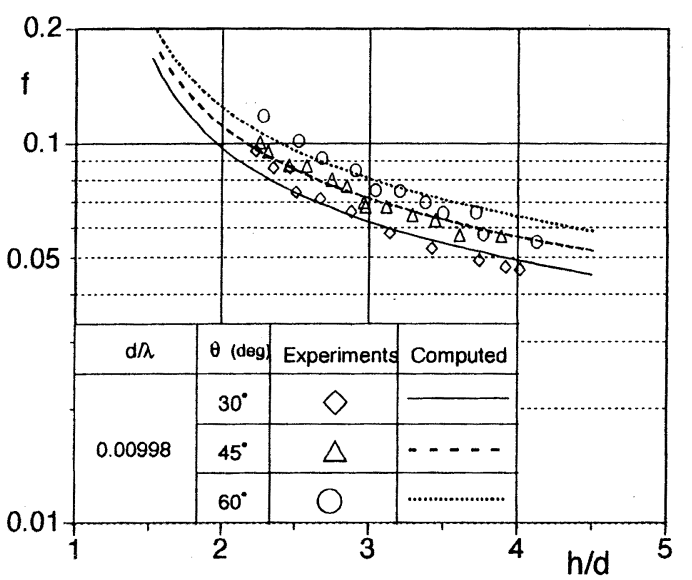

図-13 摩擦損失係数 $f$ と $(h / d, \theta)$ の関倸(Series-R)

わけではない。しかし，近年の河川工法の目的の一 つは, 流速・水深・潤辺粗度を不均一にして流れの 多様性を生久出すことにあり, 水路断面の抵抗增加 や水衝部・緩流部など水理学的に検討すべき課題を ともなう.ここでは, 河道要素の空間変化を単純化 し，開水路の特性を実験的に検討した. 最終的にこ れらの水理学的知見を河道計画に供するためには, 粗度係数など一次元的な流水抵抗の表現に帰着する 必要がある. 井田の断面分割法年に代表されるよう に, 河道内における流速や水深の不均一性を一次元 的に表現するためには，実河川における流速やせん 断力などの三次元的特性に関する知見を積为重ねる 必要がある.

\section{参考文献}

1) 福岡・藤田: 複断面河道の抵抗予測と河道計画への応 用, 土木学会論文集, No.411/ II -12, pp.63-72, 1989.

2) Parker, G. and Peterson, W.: Bar resistance of gravelbed streams, J. Hydraulic Eng., Proc.ASCE, Vol.106, HY10, pp.1559-1575, 1980.

3) 藤井・道奥 - 竹本: 粗面浅水部と滑面哚水部が交互に 配置された開水路流の抵抗特性, 第52回土木学会年次 学術講演会, 1997年.

4) 井田: 広巾員水路の定常流一断面形の影響について, 土 木学会論文集, No.69, 別冊(3-2), 1960.

(1997.9.30受付) 